\title{
Tingkat Kegemukan dan Kebugaran Jasmani Siswa Sekolah Menengah Atas Berbasis Gender
}

\author{
Andicha G Jeki ${ }^{1 *}$, Dwiko F Rizki ${ }^{2}$ \\ ${ }^{1}$ Universitas Adiwangsa Jambi \\ ${ }^{2}$ Madrasah Aliyah Negeri Insan Cendekia Jambi \\ *Correspondence email: andichagj@gmail.com
}

\begin{abstract}
Abstrak. Kegemukan dan obesitas merupakan masalah serius yang dihadapi di dunia, karena terus meningkat disemua negara. Data Riskesdas 2013 menunjukkan bahwa secara nasional masalah gemuk pada anak usia sekolah cukup tinggi, yaitu remaja sebesar $10,8 \%$. Penyebab utama kegemukan adalah kurangnya aktivitas fisik yang akan berdampak langsung pada menurunnya kebugaran jasmani. Pendidikan jasmani dan olahraga disekolah juga bertujuan untuk membina sekaligus mengembangkan potensi anak baik dalam aspek fisik, mental, sosial, emosional, moral bahkan kognitif. Penelitian ini bertujuan untuk melihat dan menganalisis tingkat kegemukan dan kebugaran jasmani pada siswa sekolah menengah atas berdasarkan jenis kelamin. Penelitian dilakukan secara observasional dengan pendekatan potong lintang. Lokasi penelitian adalah Madrasah Aliah Negeri Cendikia Jambi. Responden dipilih secara purposive sampling sejumlah 56 responden dengan membandingkan secara merata yaitu sejumlah 28:28 responden berdasarkan tingkat kegemukan dan sebaran gender. Tekhnik pengumpulan data meliputi pengisian kuesioner, pengukuran antropometri, dan tes kebugaran jasmani dilakukan secara langsung. Data dianalisis dengan uji chi square untuk melihat hubungan antara kegemukan dengan kebugaran jasmani siswa berdasarkan gender, dengan nilai signifikansi p $<0,05$ pada tingkat kemaknaan 95\%. Hasil penelitian didapatkan sejumlah 44:12 responden penelitian memiliki riwayat genetik kegemukan, sebanyak 37 reponden berusia $<17$ tahun dan 19 responden $\geq 17$ tahun. Hasil analisis chi-square didapatkan nilai $\mathrm{p}=$ $0,00(\mathrm{p}<0,05)$ pada laki-laki yang berarti ada hubungan antara kegemukan dengan kebugaran jasmani, dan nilai $\mathrm{p}=0,39(\mathrm{p}>0,05)$ pada perempuan yang berarti tidak ada hubungan antara kegemukan dengan kebugaran jasmani. Kuat hubungan secara bersamaan dianalisis menggunakan regresi binary logistic antar variabel yaitu kegemukan, umur, jenis kelamin dan riwayat genetik, dan didapatkan bahwa faktor kegemukanlah yang paling mempengaruhi variabel terikat (dependent variable) yaitu kebugaran jasmani, ditandai dengan nilai Exp.(B) 3,60 dan nilai p=0,017.
\end{abstract}

Kata kunci: Kebugaran jasmani; Kegemukan; Siswa

Abstract. Overweight and obesity are serious problems faced in the world, because it continues to increase in all countries. Riskesdas 2013 data shows that nationally, the problem of obesity in school-age children is quite high, namely adolescents at 10.8\%. The main cause of obesity is a lack of physical activity which will have a direct impact on decreasing physical fitness. Physical education and sports in schools also aim to foster and develop children's potential in physical, mental, social, emotional, moral and even cognitive aspects. This study aims to see and analyze the level of obesity and physical fitness in high school students based on gender. The study was conducted in an observational manner with a cross sectional approach. The research location is Madrasah Aliah Negeri Cendikia Jambi. Respondents selected by purposive sampling of 56 respondents by comparing evenly, namely a number of 28:28 respondents based on obesity level and gender distribution. Data collected by filling questionnaires, anthropometric measurements, physical fitness tests. Data analyzed using chi square test with a significance value of $p<0.05$ at the 95\% level of significance. The results showed 44:12 respondents in the study had a genetic history of obesity, 37 respondents aged $<17$ years and 19 respondents $\square 17$ years. The chi-square analysis results showed the $p$ value $=0.00$ $(p<0.05)$ in men, which means there is relationship between obesity and physical fitness, and $p$ value $=0.39(p>0.05)$ in women who means that there is no relationship between obesity and physical fitness. Strong relationships were simultaneously analyzed using binary logistic regression between variables, namely obesity, age, gender and genetic history, and it was found that obesity factors most influenced the dependent variable, namely physical fitness, indicated by the value of Exp. (B) 3, 60 and $p$ value = 0.017 .

Keywords: Physical fitness; Obesity; Students

\section{PENDAHULUAN}

Kegemukan merupakan masalah serius yang dihadapi di dunia, karena terus meningkat disemua negara. Tahun 2014 , sebanyak $39 \%$ penduduk dewasa $(\geq$ 18 tahun) menderita kegemukan (38\% pada laki-laki dan $40 \%$ pada perempuan). Secara umum kejadian kegemukan di dunia meningkat dua kali lipat sejak tahun 1980 - 2014 yaitu 5\% - 11\% pada laki-laki dan $8 \%$ $15 \%$ pada perempuan. Kegemukan dan obesitas menyebabkan 3,4 juta penduduk di dunia meninggal dunia setiap tahunnya (WHO, 2014).

Sementara di Indonesia, kegemukan juga merupakan masalah kesehatan masyarakat yang sedang dihadapi saat ini, menyebabkan beban ganda penyakit dan beban ganda masalah gizi. Saat pembangunan kesehatan masih menghadapi beban pengendalian penyakit menular dan gizi kurang pada penduduk, beban akibat peningkatan penyakit tidak menular (PTM) dan 
gizi lebih (kegemukan) meningkat (Kemenkes RI, 2012). Kegemukan merupakan masalah kesehatan yang serius dalam tahap perkembangan kehidupan (Evans SL, 2015).

Data Riskesdas 2013 menunjukkan bahwa secara nasional masalah gemuk pada anak usia sekolah masih tinggi, yaitu umur 5-12 tahun sebesar 18,8\% (gemuk $10 \%$ dan obesitas 8,8\%), remaja umur 13-15 tahun sebesar $10,8 \%(8,3 \%$ gemuk dan $2,5 \%$ sangat gemuk) dan remaja umur 16-18 tahun sebesar 7,3\% (5,7\% gemuk dan 1,6\% sangat gemuk). Kecenderungan prevalensi gemuk (IMT/U) pada remaja naik dari $1,4 \%$ tahun 2010 menjadi 7,3\% tahun 2013 (Kemenkes RI, 2013).

Sedangkan data Riskesdas 2018 juga menunjukkan bahwa nasional masalah gemuk pada anak usia sekolah masih terus meningkat. Dimana prevalensi status gizi anak Indonesia usia 5-12 tahun yaitu gemuk sebesar 10,8\%, dan obesitas sebesar 9,2\%. Pada perempuan dan di daerah perkotaan prevalensi lebih besar dari laki-laki dan di pedesaan. Sedangkan pada usia 13-15 tahun ditemukan remaja gemuk sebesar $11,2 \%$ dan obesitas sebesar 4,8\%. Untuk usia 16-18 tahun ditemukan remaja gemuk sebesar $9,5 \%$ dan obesitas sebesar 4,0\% (Kemenkes, 2019).

Kurangnya aktivitas fisik merupakan faktor penyebab terjadinya masalah kegemukan dan obesitas. Perkembangan pembangunan yang memudahkan akses transportasi dan penggunaan mesin dalam bekerja baik di rumah maupun di tempat kerja cenderung merubah pola hidup menjadi kurang gerak dan banyak duduk (sedentary lifestyle). Aktivitas fisik mempunyai pengaruh terhadap pengaturan berat badan. Konsumsi energi yang berlebihan namun tidak diimbangi dengan aktivitas yang cukup dapat menyebabkan penimbunan energi dalam tubuh sehingga mengakibatkan kenaikan berat badan (Kemenkes RI, 2014).

Pada anak sekolah, dimungkinkan karena keterbatasan lapangan untuk bermain dan kurangnya fasilitas untuk beraktivitas fisik menyebabkan anak lebih memilih untuk bermain di dalam rumah. Kemajuan teknologi berupa alat elektronik seperti video games, playstation, televisi dan komputer menyebabkan anak menjadi malas untuk beraktivitas (Kemenkes RI, 2014).

Sardinha et al. (2014) memperkuat pernyataan bahwa anak-anak dan remaja harus memiliki kesempatan yang lebih banyak untuk beraktivitas fisik sehingga akan meningkatkan kebugaran kardiorespirasi dan memperbaiki status berat badan anak selama sekolah, karena adanya efek sinergis dari kebugaran kardiorespirasi dan status berat badan siswa. Begitu banyaknya masalah yang akan ditimbulkan dari kegemukan diantaranya ialah hipertensi, penyakit gagal ginjal, sirosis hepatis bahkan depresi, sehingga hal ini perlu perhatian secara serius (Heber D \& Li Z, 2017).

Remaja merupakan usia peralihan dari masa kanak-kanak menuju dewasa. Pada usia remaja banyak perubahan yang terjadi. Selain perubahan fisik karena mulai matangnya sistem hormonal dalam tubuh mereka, sehingga mempengaruhi komposisi tubuh. Perubahanperubahan itu berlangsung dengan sangat cepat baik pertumbuhan tinggi maupun berat tubuhnya. Hal ini sering disebut masa pubertas dan keadaan ini sangat mempengaruhi kebutuhan gizi dari makanan mereka. Pada kondisi ini remaja akan membutuhkan asupan energi yang lebih banyak dari biasanya, namun apabila tidak diimbangi dengan aktivitas fisik yang cukup maka akan menyebabkan kegemukan (Irianto K, 2014).

Aktivitas fisik dimaksudkan untuk mengurangi gaya hidup sedentary dan meningkatkan penggunaan energi untuk mengeluarkan kalori, dan mengontrol berat badan. Aktivitas fisik perlu dilakukan secara teratur untuk meningkatkan gaya hidup sehat pada remaja (Irianto K, 2014). Penelitian ini bertujuan untuk melihat dan menganalisis tingkat kegemukan dan kebugaran jasmani pada siswa sekolah menengah atas berdasarkan jenis kelamin.

\section{METODE}

Penelitian dilakukan secara observasional dengan pendekatan potong lintang. Lokasi penelitian adalah Madrasah Aliah Negeri Cendikia Jambi, yang dilakukan pada bulan Juli s/d Desember 2020. Pengumpulan data meliputi pengisian kuesioner, pengukuran antropometri, dan tes kebugaran jasmani dilakukan secara langsung.

Populasi penelitian adalah keseluruhan dari siswa Madrasah Aliyah Negeri Insan Cendekia Jambi yang telah diberikan penjelasan dan informed concent tentang rencana penelitian. Responden dipilih secara purposive sampling sejumlah 56 responden dengan membandingkan secara merata yaitu sejumlah 28:28 (gemuk/obes: normal) berdasarkan tingkat kegemukan yang didapatkan melalui pengukuran antropometri tinggi dan berat badan siswa, serta jenis kelamin dan data karakteristik responden yang didapatkan melalui pengisian kuesioner.

Tes kebugaran jasmani menggunakan single tes (Indriati, 2010) dan kombinasi dengan tes untuk pengendalian kegemukan (Kemenkes, 2014) yaitu dengan tes lari yang dibagi berdasarkan usia, tingkat kegemukan dan jarak lari, dilakukan secara single blind dimana hanya peneliti saja yang mengetahui siapa yang menjadi subjek penelitian.

Selanjutnya data dianalisis dengan uji chi square untuk melihat hubungan antara kegemukan dengan kebugaran jasmani siswa berdasarkan gender, dengan nilai signifikansi $\mathrm{p}<0,05$ pada tingkat kemaknaan $95 \%$, dan analisis kuat hubungan antar variabel penelitian menggunakan regresi binary logistic untuk melihat dan membandingkat variabel bebas manakah yang paling kuat mempengaruhi terikat dalam penelitian. 


\section{HASIL DAN PEMBAHASAN}

Hasil penelitian didapatkan sejumlah 44:12 responden penelitian memiliki riwayat genetik kegemukan, sebanyak 37 reponden berusia $<17$ tahun dan 19 responden $\geq 17$ tahun.

Untuk mengetahui sebaran data karakteristik dari responden pada penelitian ini dapat dilihat pada Tabel berikut:

Tabel 1. Sebaran Data Karakteristik

\begin{tabular}{ccc}
\hline Variabel & Kriteria & Jumlah \\
\hline Umur & $<17$ Tahun & 37 \\
& $\geq 17$ Tahun & 19 \\
Jenis Kelamin & Laki-laki & 28 \\
& Perempuan & 28 \\
Riwayat Genetik & Ya & 44 \\
& Tidak & 12 \\
Kegemukan & Gemuk / Obes & 28 \\
& Normal & 28 \\
\hline
\end{tabular}

Sumber: Data Primer

Hasil analisis chi-square didapatkan nilai $\mathrm{p}=0,00$ $(\mathrm{p}<0,05)$ pada laki-laki yang berarti ada hubungan antara kegemukan dengan kebugaran jasmani, dan nilai $\mathrm{p}=$ $0,39(\mathrm{p}>0,05)$ pada perempuan yang berarti tidak ada hubungan antara kegemukan dengan kebugaran jasmani (Sumber: Data Primer).

Selain itu, dari hasil analisis kuat hubungan secara bersamaan dilakukan untuk melihat antar variabel penelitian manakah yang paling mempengaruhi dari variabel terikat, menggunakan regresi binary logistic antar variabel yaitu kegemukan, umur, jenis kelamin dan riwayat genetik, dan didapatkan bahwa faktor kegemukanlah yang paling mempengaruhi variabel terikat (dependent variable) yaitu kebugaran jasmani, ditandai dengan nilai Exp.(B) 3,60 dan nilai $p=0,017$ (Sumber: Data Primer).

Aktivitas fisik mempunyai pengaruh terhadap pengaturan berat badan. Konsumsi energi yang berlebihan namun tidak diimbangi dengan aktivitas yang cukup dapat menyebabkan penimbunan energi dalam tubuh sehingga mengakibatkan kenaikan berat badan (Kemenkes RI, 2014).

Sardinha et al. (2014) memperkuat pernyataan bahwa anak-anak dan remaja harus memiliki kesempatan yang lebih banyak untuk beraktivitas fisik sehingga akan meningkatkan kebugaran kardiorespirasi dan memperbaiki status berat badan anak selama sekolah, karena adanya efek sinergis dari kebugaran kardiorespirasi dan status berat badan siswa. Begitu banyaknya masalah yang akan ditimbulkan dari kegemukan diantaranya ialah hipertensi, penyakit gagal ginjal, sirosis hepatis bahkan depresi, sehingga hal ini perlu perhatian secara serius (Heber D \& Li Z, 2017).

Aktivitas fisik dimaksudkan untuk mengurangi gaya hidup sedentary dan meningkatkan penggunaan energi untuk mengeluarkan kalori, dan mengontrol berat badan. Aktivitas fisik perlu dilakukan secara teratur untuk meningkatkan gaya hidup sehat pada remaja (Irianto K, 2014).

Remaja merupakan usia peralihan dari masa kanak-kanak menuju dewasa. Pada usia remaja banyak perubahan yang terjadi. Selain perubahan fisik karena mulai matangnya sistem hormonal dalam tubuh mereka, sehingga mempengaruhi komposisi tubuh. Perubahanperubahan itu berlangsung dengan sangat cepat baik pertumbuhan tinggi maupun berat tubuhnya. Hal ini sering disebut masa pubertas dan keadaan ini sangat mempengaruhi kebutuhan gizi dari makanan mereka. Pada kondisi ini remaja akan membutuhkan asupan energi yang lebih banyak dari biasanya, namun apabila tidak diimbangi dengan aktivitas fisik yang cukup maka akan menyebabkan kegemukan (Irianto K, 2014).

\section{SIMPULAN}

Kegemukan sangat mempengaruhi kebugaran jasmani siswa, sehingga aktivitas fisik perlu dilakukan secara teratur untuk meningkatkan gaya hidup sehat pada remaja. pendidikan jasmani dan olahraga disekolah bertujuan untuk membina dan mengembangkan potensi anak baik dalam aspek fisik, mental, sosial, emosional, moral bahkan kognitif. anak-anak dan remaja harus memiliki kesempatan yang lebih banyak untuk beraktivitas fisik sehingga memunculkan efek sinergis terhadap kebugaran kardiorespirasi dan status kesehatan siswa.

\section{DAFTAR PUSTAKA}

Evans, SL. (2015). Nutrition, Helath and Disease : A Lifespan Approach. John Wiley \& Sons, Ltd The Atrium Southern Gate Chicester, West Sussex, UK.

Irianto, K. (2014). Gizi seimbang dalam kesehatan reproduksi. Alfabeta, Bandung.

Heber, D \& Li, Z. (2017). Primary Care Nutrition: The Nutrition Prescription. Taylor and Francis Group LLC, US

Indriati, (2010). Antropometri Untuk Kedokteran, Keperawatan, Gizi Dan Olahraga. Klaten: Intan Sejati.

Kementerian Kesehatan RI. (2012). Strategi Nasional Penerapan Pola Konsumsi Makanan Dan Aktivitas Fisik Untuk Mencegah Penyakit Tidak menular. Jakarta: Direktorat Jenderal Bina Gizi dan Kesehatan Ibu dan Anak.

Kementerian Kesehatan RI. (2013). Riset Kesehatan Dasar 2013. Jakarta: Badan Penelitian dan Pengembangan Kesehatan.

Kementerian Kesehatan RI. (2014). Pedoman Penyelenggaraan Pelatihan Pencegahan dan Penanggulangan Kegemukan dan Obesitas Pada Anak Sekolah.Jakarta: Direktorat Jenderal bina Gizi dan Kesehatan Ibu dan Anak. 
Andicha G Jeki dan Dwiko F Rizki, Tingkat Kegemukan dan Kebugaran Jasmani Siswa Sekolah Menengah Atas Berbasis Gender

Kementerian Kesehatan RI. (2019). Riset Kesehatan Dasar 2018. Jakarta: Badan Penelitian dan Pengembangan Kesehatan.

Sardinha, L.B., Marques, A., Martins, S., Palmeira, A \& Minderico, C. (2014). Fitness, fatness, and academic performance in seventh-grade elementary school students. BMC Pediatrics, 14:176.

World Health Organization. (2014). Global Status Report On Non-Communicable Diseases. Library Cataloguing in Publication Data. ISBN 978924 156485 4. (NLM classification: WT 500). 